\title{
BUDAYA MAHASISWA DALAM MENGGUNAKAN PIRATED BOOKS DI PERGURUAN TINGGI KOTA PEKANBARU
}

\author{
Alfiah \\ Universitas Islam Negeri Sultan Syarif Kasim Riau \\ Email: alfiah.tarmizi68@gmail.com \\ Ismail \\ Universitas Islam Negeri Sultan Syarif Kasim Riau \\ Email: ismailkincai@gmail.com \\ Darni \\ Universitas Islam Negeri Sultan Syarif Kasim Riau \\ Email: dahnylfitri@gmail.com
}

\begin{abstract}
This study aimed to know the culture of students in using pirated books. The location of the study was conducted at State Islamic University of Sultan Syarif Kasim Riau), University of Riau, Universitas Islam Riau, and Lancang Kuning University in Pekanbaru City. Based on the analysis of student economic factors, it shows that the student culture in using pirated books was not because of economic factors. It was evidenced by most of the students with good economic conditions or in the middle to lower class. Based on students' understanding of Copyright, it indicated that students comprehend and understand about copyright. However, respondents considered the copy of the book for the benefit of education does not violate the copyright because to facilitate the science. Actually a photocopy of a book for the benefit of education to facilitate the demand for science is basically an act of copyright infringement because it includes actions to reproduce without permission and disseminate it. Student's attitudes to regular ordinary photocopies/copies are familiar with copier/pirate books. Based on the habits (culture) of students in buying reference books where the purchase of photocopy reference books/pirates is already a student habit.
\end{abstract}

Keywords: student, pirated books, copyright

\section{A. Pendahuluan}

Pembajakan dan pelanggaran hak cipta telah menjadi hal yang lumrah di zaman sekarang. Salah satu bentuk budaya pelanggran hak cipta yang sering dilakukan dan dianggap hal yang biasa adalah menggandakan sebuah buku dengan cara fotokopi. 
Alfiah, Ismail, Darni: Budaya Mahasiswa dalam Menggunakan Pirated Books...

Lebih membuat mirisnya lagi, pelanggaran ini banyak terjadi lembaga pendidikan seperti sekolah dan perguruan tinggi dan budaya memfotokopi buku dianggap biasa oleh semua orang, padahal dalam buku tersebut melekat hak cipta seseorang sehingga apabila dilanggar dapat menimbulkan tindakan pidana. Undang-undang yang berkaitan dengan hak cipta adalah Undang-Undang Nomor 19 tahun 2002 pasal 1 ayat 1.

Anggapan yang berkembang di kalangan mahasiswa bahwa harga buku yang mahal dan sulit ditemukannya buku yang asli menjadi referensi sebagian dosen serta peredarannya terbatas atau tidak diterbitkan lagi mendorong munculnya paraktek buku fotokopi/bajakan. Selain itu, anggapan lain yang membuat buku fotokopi/bajakan berkembang sangat pesat adalah adanya penanaman nilai pemahaman bahwa membeli buku fotokopi/bajakan bukanlah suatu hal yang tercela. Bagi mahasiswa, memiliki buku bukan lah suatu hal yang murah. Namun mahasiswa memiliki cara untuk mendapatkan buku referensi kuliah yang murah dengan membeli buku referensi kuliah bajakan (ilegal) atau menggandakan buku tersebut dengan cara fotokopi kemudian membelinya. Bahkan sebagian berpendapat bahwa dengan membeli buku fotokopi/bajakan merupakan ciri khas dan budayanya mahasiswa. Tentu anggapan ini tidak benar dan harus diluruskan.

Menurut Sayid, kebiasaan adalah pengulangan sesuatu secara terus-menerus atau dalam sebagian besar waktu dengan cara yang sama dan tanpa hubungan akal, atau dia adalah sesuatu yang tertanam di dalam jiwa dari hal-hal yang berulang kali terjadi dan diterima tabiat. Manusia bisa menyimpulkan bahwa manusia melakukan kebiasaan tanpa berpikir karena hal tersebut telah tertanam dalam jiwa manusia dan menjadi tabiat manusia. ${ }^{1}$ Dapat disimpulkan kebiasaan adalah respon dari individu. Artikata.com mendefinisikan kebiasaan adalah pola untuk melakukan tanggapan terhadap situasi tertentu yang dipelajari oleh seorang individu dan yang dilakukannya secara berulang untuk hal yang sama. ${ }^{2}$

Kemudian dalam pandangan Islam perbuatan semacam itu bisa termasuk kategori 'pencurian' kalau dilakukan dengan sembunyi-sembunyi dan diambil dari tempat penyimpanan karya tulis itu atau disebut 'perampasan/perampokan' kalau dilakukan dengan terang-terangan dan kekerasan serta 'pencopetan' kalau dilakukan

\footnotetext{
${ }^{1}$ Muhammad Sayid, Kebiasaan Baik dan Buruk dalam Hidup Manusia (Jakarta: Gema Insani Press, 2006), 347

${ }^{2}$ https://artikata.com/arti-359975-kebiasaan.html, di akses pada tanggal 18 Maret 2017
} 
dengan sembunyi-sembunyi dan di luar tempat penyimpanannya yang semestinya. Dan disebut 'penggelapan/khianat' kalau dilakukan dengan melanggar amanat/ perjanjiannya.

Menurut teori klasik Freud, kepribadian manusia tersusun dari tiga sistem pokok, yaitu id, ego dan superego. Id adalah keinginan manusia terhadap sesuatu. Superego adalah lingkungan yang mendukung tercapainya keinginan manusia atau keinginan yang dimilikinya. Sedangkan ego adalah hal yang mengendalikan keduanya, id dan superego. Dalam hal ini ego sangat menentukan manusia dalam mengambil keputusan, apakah ia akan melaksanakan dan memenuhi keinginannya atau membatalkannya id dan superego. Tiga unsur $i d$, ego dan superego inilah pembentuk kepribadian total manusia. Di mana ketiganya tidak bisa dipisahkan satu sama lain. Namun, masing-masing bagian dari kepribadian total ini mempunyai fungsi, sifat, komponen, prinsip kerja, dinamisme dan mekanisme tersendiri.

Pada studi kasus mengenai kecenderungan perilaku mahasisa Indonesia yang cenderung membeli buku bajakan, dapat ditinjau bahwa keinginan (id) di sini adalah keinginan untuk memiliki buku bajakan tertentu. Faktor ego adalah rendahnya kualitas mental bangsa Indonesia. Sedangkan lingkungan (superego) dalam hal ini adalah maraknya tempat-tempat yang menawarkan buku bajakan dengan harga yang lumayan sangat murah dibandingkan dengan jika harus membeli buku bajakan yang original. Selain itu penegakan hukum yang sangat buruk, serta kondisi perekonomian bangsa Indonesia yang rata-rata masih hidup di bawah garis kemiskinan merupakan lingkungan yang cukup mendukung terciptanya kebiasaan untuk membeli buku bajakan tersebut.

Merujuk kepada teori etika, di mana memiliki peranan penting dalam melegitimasi segala perbuatan dan tindakan yang dilihat dari sudut pandang moralitas yang telah disepakati oleh masyarakat. Dalam prakteknya, terkadang penerapan nilai etika hanya dilakukan sebatas persetujuan atas standar moral yang telah disepakati untuk tidak dilanggar. Norma moral yang menjadi standar masyarakat untuk menentukan baik buruknya perilaku dan tindakan seseorang, terkadang hanya dianggap suatu aturan yang disetujui bersama tanpa dipertimbangkan mengapa aturan-aturan moral tersebut harus kita patuhi. Untuk itu, pemikiran-pemikiran yang lebih mendalam mengenai alasan-alasan mengapa kita perlu berperilaku yang etis sesuai dengan normanorma moral yang telah disepakati, melahirkan suatu bentuk teori etika yang 
Alfiah, Ismail, Darni: Budaya Mahasiswa dalam Menggunakan Pirated Books...

menyediakan kerangka untuk memastikan benar tidaknya keputusan moral. Salah satunya adalah pemikiran etika deontology, yang mengatakan bahwa penilaian baik atau buruknya suatu tindakan didasarkan pada penilaian apakah tindakan itu sendiri sebagai baik atau buruk. Sehingga dapat dikatakan bahwa pendekatan deontology ini berbeda dalam prinsipnya dengan utilitarianisme yang berpendapat bahwa moralitas suatu tindakan tergantung pada konsekuensinya. Sedangkan etika teleology mengukur baik dan buruknya suatu tindakan berdasarkan tujuan yang ingin dicapai dengan tindakan itu atau berdasarkan akibat yang ditimbulkan oleh tindakan itu. Artinya, teleology bisa diartikan sebagai pertimbangan moral akan baik buruknya suatu tindakan yang dilakukan.

Fokus tulisan ini adalah menganalisis faktor yang membatasi mahasiswa membeli buku original, menganalisis bagaimana pemahaman mahasiswa tentang hak cipta, menganalisis bagaimana mahasiswa bersikap akan buku fotokopi/bajakan dan menganalisis bagaimana kebiasaan (budaya) mahasiswa dalam membeli buku rujukan kuliah. dalam penelitian ini juga, tujuan yang ingin dicapai adalah untuk mengetahui analisis faktor yang membatasi mahasiswa membeli buku original, untuk mengetahui analisis bagaimana pemahaman mahasiswa tentang hak cipta, untuk mengetahui analisis bagaimana mahasiswa bersikap akan buku fotokopi/bajakan dan untuk mengetahui analisis bagaimana kebiasaan (budaya) mahasiswa dalam membeli buku rujukan kuliah.

Tulisan ini diharapkan dapat memberi manfaat, baik yang bersifat teoritis maupun praktis. Secara teoritis manfaat dari hasil penelitian ini diharapkan dapat menambah wawasan keilmuan mengenai fenomena membeli buku bajakan yang terjadi pada mahasiswa dan implementasi Undang-Undang Hak Cipta Nomor 19 tahun 2002. Selain itu, penelitian ini sebagai bahan dasar bagi penelitian selanjutnya. Secara praktis manfaat dari penelitian ini diharapkan mengurangi tingkat pembajakan. Moral mahasiswa untuk malu membajak atau menggunakan produk bajakan serta menghargai hasil karya orang lain perlu ditumbuhkan dalam diri.

\section{B. Metode Penelitian}

\section{Jenis dan Pendekatan Penelitian}

Jenis penelitian ini adalah deskriptif, yaitu penelitian yang berusaha mendeskripsikan suatu gejala, peristiwa, kejadian yang terjadi. Pendekatan yang 
digunakan adalah pendekatan kuantitatif. Data yang digunakan dalam penelitian ini adalah data primer yang diperoleh dari penyebaran/kuesioner kepada mahasiswa di berbagai perguruan tinggi yang berada di Kota Pekanbaru.

\section{Lokasi Penelitian}

Lokasi penelitian dilakukan di Universitas Islam Negeri Sultan Syarif Kasim Riau (UIN Suska Riau), Universitas Riau (UR), Universitas Islam Riau (UIR), dan Universitas Lancang Kuning (UNILAK) yang ada di Kota Pekanbaru.

\section{Populasi dan Sampel}

Populasi dalam penelitian ini adalah mahasiswa yang kuliah diperguruan tinggi di Universitas Islam Negeri Sultan Syarif Kasim Riau (UIN Suska Riau), Universitas Riau (UR), Universitas Islam Riau (UIR), dan Universitas Lancang Kuning (UNILAK) yang menjadi lokasi penelitian, sedangkan teknik pengambilan sampel yang digunakan penulis adalah nonprobability sampling dengan tipe probability sampling dengan model teknik sampel acak yang memberikan kesempatan yang sama bagi anggota populasi yang terpilih, dan sampelnya adalah 100 orang di masing-masing perguruan tinggi yang menjadi tempat penelitian.

\section{Jenis dan Sumber Data}

Jenis data yang akan digunakan dalam penelitian ini adalah data primer yaitu data yang langsung diperoleh dari lapangan melaui wawancara, observasi, kuisioner. Responden yaitu mahasiswa-mahasiswa di perguruan tinggi di Universitas Islam Negeri Sultan Syarif Kasim Riau (UIN Suska Riau), Universitas Riau (UR), Universitas Islam Riau (UIR), dan Universitas Lancang Kuning (UNILAK). Jenis data sekunder berupa jenis data yang sudah tersedia sehingga peneliti hanya mencari dan mengumpulkan penulisan terhadap kajian/tulisan, buku, jurnal, aturan perundang-undangan dan pendapat pakar tentang masalah yang dibahas.

\section{Teknik Pengumpulan Data}

Teknik pengumpulan data dalam penelitian ini adalah kuesioner (angket) dan dokumentasi.

\section{Hasil Penelitian dan Pembahasan}

Kemajuan teknologi tak selamanya dapat diakomodasi oleh hukum secara baik, dalam hal fotokopi, hukum telah memberikan perlindungan atas hak kekayaan 
intelektual, termasuk di dalamnya hak cipta buku, terasa tidak tepat dan kurang efektif dalam penerapannya. Dalam praktek, fotokopi tentu telah menunjukkan adanya ketimpangan sebuah aturan hukum dengan proses kehidupan dalam masyarakat. Peneliti melihat gejala ini dari faktor ekonomi mahasiswa, pemhaman mahasiswa tentang hak cipta, sikap mahasiswa akan buku fotokopi/bajakan, dan kebiasaan (budaya) mahasiswa dalam membeli buku rujukan kuliah. Pembahasan tersebut dijelaskan sebgai berikut:

\section{Analisis Faktor Ekonomi Mahasiswa}

Kondisi ekonomi mahasiswa dapat dilihat berdasarkan frekuensi belanja bulanan mahasiswa, sebagian besar mahasiswa memiliki belanja bulanan Rp 1.000 .000 - Rp 2.000.000 ada sebanyak 193 mahasiswa (48,25\%). Sebagian lagi mahasiswa memiliki belanja bulanan antara < Rp 1.000.000 sebanyak 172 mahasiswa (43\%). Sebagian kecil mahasiswa memiliki belanja bulanan di atas Rp. 2.000.000 sebanyak 35 mahasiswa $(8,75 \%)$. Artinya, belanja bulanan mahasiswa termasuk kalangan menegah ke bawah dengan kondisi keluarga mahasiswa yang ekonomi mapan.

Kondisi ekonomi mahasiswa juga dilihat kenderaan yang digunakan menuju kampus, sebagian besar mahasiswa menggunakan sepeda motor menuju kampus ada sebanyak 309 mahasiswa (77,25\%). Sebagian lagi mahasiswa menggunakan angkutan umum menuju kampus ada sebanyak 57 mahasiswa (14,25\%). Sebagian mahasiswa menggunakan sepeda menuju kampus ada sebanyak 23 mahasiswa (5,75\%). Dan sebagian kecil menggunakan mobil menuju kampus ada sebanyak 11 mahasiswa $(2,75 \%)$. Artinya kebanyakan mahasiswa menggunakan kenderaan pribadi ke kampus yaitu sepeda motor.

Kondisi ekonomi mahasiswa juga dilihat dari harga smartphone/handphone yang dimiliki mahasiswa, sebagian besar mahasiswa menggunakan smartphone/handphone dengan harga Rp. 1.000 .000 - Rp. 2.0000.000 ada sebanyak 304 mahasiswa (76\%). Sebagian lagi mahasiswa menggunakan smartphone/handphone kurang dari Rp. 1.000.000 sebanyak 67 mahasiswa (16,75\%). Sebagian kecil mahasiswa menggunakan smartphone/handphone dengan harga lebih dari Rp. 2.000 .000 sebanyak 29 mahasiswa (7,25\%). Jadi sebagian besar mahasiswa sebanyak 304 mahasiswa (76\%) menggunakan smartphone/handphone dengan harga Rp. 1.000.000 - Rp. 2.000.000. Dapat dikatakan bahwa smartphone/handphone yang dipakai termasuk dalam kategori harga middle-level (kelas menengah). 
Kondisi ekonomi mahasiswa juga dilihat dari pekerjaan orang tua mahasiswa. Sebagian besar pekerjaan orang tua mahasiswa adalah petani sebanyak 176 mahasiswa (44\%). Sebagian lagi pekerjaan orang tua mahasiswa adalah PNS sebanyak 143 mahasiswa $(35,75 \%)$. Sisanya lagi adalah wiraswasta sebanyak 46 mahasiswa $(11,5 \%)$ dan Pedagang sebanyak 35 mahasiswa (8,75\%). Jadi sebagian besar mahasiswa sebanyak 176 mahasiswa (44\%) pekerjaan orang tua mahasiswa adalah petani dengan kondisi ekonomi yang cukup baik. Hal ini di buktikan dengan frekuensi belanja bulanan mahasiswa sebagian besar mahasiswa memiliki belanja Rp 1.000.000 - Rp 2.000.000.

Kemudian dilihat dari alokasi belanja bulanan yang disisihkan mahasiswa, sebagian besar mahasiswa mengalokasi belanja untuk membeli buku kurang dari Rp. 500.000 sebanyak 381 mahasiswa (95,25\%). Sebagian mahasiswa mengalokasi belanja untuk membeli buku antara Rp. 500.000 - Rp. 1.0000 .000 sebanyak 16 mahasiswa (4\%), sebagian mahasiswa mengalokasi belanja untuk membeli buku lebih dari Rp. 1.000.000 sebanyak 3 mahasiswa (0,75\%). Jadi sebagian besar mahasiswa sebanyak 381 mahasiswa $(95,25 \%)$ mengalokasi belanja untuk membeli buku kurang dari Rp. 500.000 .

Dari temuan penelitian, kondisi ekonomi mahasiswa dapat disimpulkan termasuk dalam golongan menengah ke bawah. Hal ini dibuktikan frekuensi belanja bulanan mahasiswa sebagian besar antara Rp 1.000.000-Rp 2.000.000, kenderaan yang digunakan menuju kampus sebagian besar adalah sepeda ada sebanyak 309 mahasiswa (77,25\%), menggunakan smartphone/handphone dengan harga Rp. 1.000 .000 - Rp. 2.000.000 sebanyak 304 mahasiswa (76\%), dan sebagian besar pekerjaan orang tua mahasiswa adalah petani sebanyak 176 mahasiswa (44\%). Hasil penelitian menunjukan kondisi ekonomi mahasiswa tidak mepengaruhi mahasiswa dalam membeli buku referensi yang original/asli.

\section{Pemahaman Mahasiswa Tentang Hak Cipta}

Pemahaman mahasiswa tentang hak cipta, di mana sebagian besar mahasiswa sebanyak $274(68,5 \%)$ berpendapat adalah suatu hak agar ciptaannya tidak ditiru oleh orang lain. Ada sebanyak 89 mahasiswa $(22,25 \%)$ berpendapat bahwa hak cipta adalah hak untuk mendapat hasil ekonomis dari ciptaannya. 37 mahasiswa $(9,25 \%)$ berpendapat bahwa hak cipta adalah hak pencipta untuk mengumumkan atau memperbanyak ciptaannya. Jadi sebagian besar mahasiswa sebanyak 274 mahasiswa 
Alfiah, Ismail, Darni: Budaya Mahasiswa dalam Menggunakan Pirated Books...

$(68,5 \%)$ berpendapat bahwa hak cipta adalah suatu hak agar ciptaannya tidak ditiru oleh orang lain. Pengertian hak cipta sudah diatur dalam Undang-Undang Hak Cipta Pasal 1 ayat (1) dan juga diatur dalam Pasal 2 ayat (1). Pengertian Hak Cipta menurut Pasal 1 ayat (1) dan Pasal 2 ayat (1) dapat disimpulkan bahwa hak cipta yaitu hak bagi pencipta atau pemegang hak cipta untuk mengumumkan atau memperbanyak ciptaannya. Jadi pendapat sebagian besar mahasiswa tentang pengertian hak cipta bahwa suatu hak agar ciptaannya tidak ditiru oleh orang lain masih terlalu sempit dibanding dengan pengertian hak cipta menurut Pasal 1 ayat (1) dan Pasal 2 ayat (1).

Selanjutnya, peneliti juga mendapatkan hasil pemahaman mahasiswa yang dianggap sebagai pencipta adalah seseorang yang melahirkan suatu ciptaan berdasar kreativitasnya yang dituangkan ke dalam bentuk yang khas sebanyak 357 mahasiswa $(89,25 \%)$. Ada sebanyak 37 mahasiswa $(9,25 \%)$ berpendapat bahwa pencipta adalah orang yang pertama kali mengumumkan suatu hasil karya cipta. Ada sebanyak 6 mahasiswa $(1,5 \%)$ berpendapat bahwa pencipta adalah orang yang menciptakan karya dan hanya digunakan sendiri. Jadi sebagian besar mahasiswa sebanyak 357 mahasiswa $(89,25 \%)$ berpendapat bahwa yang dianggap sebagai pencipta adalah seseorang yang melahirkan suatu ciptaan berdasar kreativitasnya yang dituangkan ke dalam bentuk yang khas. Sedangkan pengertian pencipta menurut Undang-Undang Hak Cipta Pasal 1 ayat (2) adalah seorang atau beberapa orang secara bersama-sama yang atas inspirasinya melahirkan suatu ciptaan berdasarkan kemampuan pikiran, imajinasi, kecekatan, keterampilan, atau keahlian yang dituangkan ke dalam bentuk yang khas dan bersifat pribadi. Jadi pengertian pencipta menurut pendapat sebagian besar mahasiswa sudah sesuai dengan pengertian pencipta menurut Undang-Undang Hak Cipta Pasal 1 ayat (2) yang sudah disampaikan di atas.

Pemahaman mahasiswa yang termasuk dalam pelanggaran hak cipta, di mana ada sebanyak 37 mahasiswa $(9,25 \%)$ berpendapat bahwa yang tidak dianggap sebagai pelanggaran Hak Cipta adalah menggandakan buku tanpa izin untuk kepentingan pendidikan. Ada 340 mahasiswa (85\%) berpendapat bahwa yang tidak dianggap sebagai pelanggaran hak cipta adalah perbanyakan lambang negara dan lagu kebangsaan menurut sifatnya yang asli. Dan 23 mahasiswa $(5,75 \%)$ berpendapat bahwa yang tidak dianggap sebagai pelanggaran hak cipta adalah pengutipan untuk kepentingan penulisan karya ilmiah tanpa mencantumkan sumber. Jadi sebagian besar mahasiswa sebanyak 
340 mahasiswa (85\%) berpendapat bahwa yang tidak dianggap sebagai pelanggaran hak cipta adalah perbanyakan lambang negara dan lagu kebangsaan menurut sifatnya yang asli. Artinya, sebagian besar mahasiswa sudah mengetahui jika perbanyakan lambang negara dan lagu kebangsaan menurut sifatnya yang asli tidak termasuk sebagai pelanggaran hak cipta dan sudah sesuai dengan Pasal 14 Undang-Undang Hak Cipta.

Pemahaman mahasiswa memfotokopi buku tidak melanggar hak cipta, di mana ada sebanyak 167 mahasiswa (41,75\%) berpendapat jika melakukan fotokopi buku bukan untuk dikomersilkan tidak melanggar hak cipta karena hanya diri sendiri. Ada 194 mahasiswa (48,5\%) berpendapat jika melakukan fotokopi buku untuk kepentingan pendidikan tidak melanggar hak cipta karena untuk mempermudah menuntut ilmu pengetahuan. Dan 39 mahasiswa $(9,75 \%)$ berpendapat jika melakukan fotokopi buku tidak merubah isi dan kandungan buku tersebut tidak termasuk melanggar hak cipta. Jadi sebagian besar mahasiswa sebanyak 194 mahasiswa (48,5\%) jika melakukan fotokopi buku untuk kepentingan pendidikan tidak melanggar hak cipta karena untuk mempermudah menuntut ilmu pengetahuan. Sebenarnya fotokopi buku untuk kepentingan pendidikan tidak melanggar hak cipta untuk mempermudah menuntut ilmu pengetahuan pada dasarnya adalah sebuah tindakan pelanggaran hak cipta karena termasuk tindakan memperbanyak tanpa izin dan menyebarluaskannya.

\section{Sikap Mahasiswa terhadap Buku Fotokopi/Bajakan}

Sikap mahasiswa akan buku fotokopi/bajakan, di mana menurut sebagian besar mahasiswa sebanyak 218 mahasiswa $(54,5 \%)$ berpendapat bahwa buku bajakan adalah buku yang dicetak oleh pencetak yang tidak mempunyai hak terkait dan kualitasnya lebih jelek. Kalau buku tersebut dicetak oleh pencetak yang tidak mempunyai hak terkait, maka dengan kata lain buku tersebut merugikan bagi yang mempunyai hak, bisa pengarang maupun penerbit. Jadi pada intinya buku bajakan melanggar hak cipta khususnya hak ekonomi, karena yang mempunyai hak terkait tidak mendapatkan keuntungan secara ekonomis.

Selanjutnya, sikap mahasiswa akan buku fotokopi/bajakan dilihat dari jumlah buku fotokopi yang dimiliki mahasiswa menunjukkan bahwa sebagian besar mahasiswa yang memiliki jumlah buku fotokopi antara 4-6 buah buku sebanyak 182 mahasiswa $(45,5 \%)$. Sebagian mahasiswa jumlah buku fotokopi yang dimiliki antara 7-9 buah buku sebanyak 106 mahasiswa (26,5\%). Sebagian mahasiswa jumlah buku fotokopi yang 
Alfiah, Ismail, Darni: Budaya Mahasiswa dalam Menggunakan Pirated Books...

dimiliki kurang dari 3 buah buku sebanyak 85 mahasiswa (21,25\%). Sebagian mahasiswa jumlah buku fotokopi yang dimiliki di atas 10 buah buku sebanyak 27 mahasiswa (6,75). Jadi sebagian besar mahasiswa sebanyak 182 mahasiswa $(45,5 \%)$ memiliki jumlah buku fotokopi antara 4-6 buah buku.

Kemudian, sikap mahasiswa akan buku fotokopi/bajakan dilihat dari perasaan mahasiswa melakukan fotokopi buku referensi kuliah menunjukkan bahwa sebagian besar mahasiswa yang melakukan fotokopi buku referensi kuliah merasa biasa-biasa saja sebanyak 281 mahasiswa (70,25\%). Sebagian mahasiswa yang melakukan fotokopi buku referensi kuliah merasa bangga, karena lebih praktis sebanyak 32 mahasiswa (8\%), sebagian mahasiswa yang melakukan fotokopi buku referensi kuliah merasa bersalah, karena telah melanggar aturan sebanyak 87 mahasiswa (21,75\%). Jadi sebagian besar mahasiswa sebanyak 281 mahasiswa (70,25\%) yang melakukan fotokopi buku referensi kuliah merasa biasa-biasa saja. Setelah melakukan kegiatan fotokopi buku, mahasiswa tidak ada rasa khawatir atau rasa bersalah karena telah melakukan tindakan yang termasuk melanggar peraturan. Sehingga seolah-olah memfotokopi buku sudah menjadi hal biasa di kalangan mahasiswa.

Sikap mahasiswa akan buku fotokopi/bajakan dilihat dari tempat membeli buku bajakan, mahasiwa menunjukan ada sebanyak 331 mahasiswa $(82,75 \%)$ berpendapat bahwa tempat membeli buku bajakan adalah kios sekitar kampus. Ada 26 mahasiswa $(6,5 \%)$ berpendapat bahwa tempat membeli buku bajakan adalah tempat-tempat umum seperti terminal, stasiun, dan lain-lain. Dan ada 43 mahasiswa $(10,75 \%)$ berpendapat bahwa tempat membeli buku bajakan kios-kios yang memang menjual buku bajakan. Jadi sebagian besar mahasiswa sebanyak 331 mahasiswa $(82,75 \%)$ berpendapat bahwa tempat membeli buku bajakan adalah kios di sekitar kampus. Hal ini terjadi dikarenakan di sekitar kawasan kampus telah menjamur kios-kios yang menawarkan jasa fotokopi buku dengan harga yang miring. Sehingga tidak ada kesulitan mahasiswa dalam mencari tempat Fotokopian buku referensi kuliah.

Selain itu reaksi orang sekitar tentang membeli buku bajakan/fotokopi menunjukan sebagian besar mahasiswa sebanyak 253 mahasiswa $(63,25 \%)$ berpendapat bahwa reaksi orang-orang membeli buku bajakan/fotokopi adalah dianggap biasa-biasa saja. Artinya, kegiatan memfotokopi buku bukan dianggap hal yang tabu atau tercela. Kondisi seperti ini selaras dengan teori teleology, yang mengatakan walaupun sebuah 
tindakan dinilai salah menurut hukum, tetapi jika itu bertujuan dan berakibat baik, maka tindakan itu dinilai baik.

Dari sisi kualitas buku sebagian besar mahasiswa sebanyak 257 mahasiswa $(64,25 \%)$ berpendapat tentang kualitas buku bajakan/fotokopi tidak sama kualitasnya dengan buku original. Walaupun tidak sama kualitasnya dengan buku original, namun buku bajakan/fotokopi tetap diminati kalangan mahasiswa. Menurut pendapat mahasiswa buku bajakan cukup mudah untuk didapatkan, karena memang ada kios-kios yang menyediakan atau menjual buku bajakan dilingkungan mereka. Sesuai dengan teori klasik Freud, di mana superego adalah lingkungan yang mendukung tercapainya keinginan manusia atau keinginan yang dimilikinya. Dalam hal ini adalah maraknya tempat-tempat yang menawarkan buku bajakan dengan harga yang lumayan sangat murah dibandingkan dengan jika ia harus membeli buku bajakan yang original.

\section{Kebiasaan (Budaya) Mahasiswa dalam Membeli Buku Rujukan Kuliah}

Kebiasaan dilakukan secara berulang-ulang yang menjadi respon dari suatu perilaku. Jika kebiasaan adalah respon dari perilaku maka respon yang didapatkan dari perbuatan yang sama tidak akan sama karena perbuatan manusia dipengaruhi oleh pengetahuan dan pengalaman hidupnya. Menurut Asih dan Pratiwi (2010) kebiasaan adalah perbuatan sehari-hari yang dilakukan secara berulang-ulang dalam hal yang sama, sehingga menjadi adat kebiasaan dan ditaati oleh masyarakat. ${ }^{3}$

Kebiasaan (budaya) mahasiswa dalam membeli buku rujukan kuliah ketika sulit mendapatkan buku referensi original dimana sebagian besar mahasiswa sebanyak 201 mahasiswa $(50,25 \%)$ berpendapat bahwa tindakan mahasiswa ketika sulit mendapatkan buku referensi original adalah dengan meminjam di perpustakaan. Namun, pada pilihan kedua ketika buku itu tidak ada di perpustakaan mahasiswa memfotokopi buku tersebut sebanyak 167 mahasiswa $(41,75 \%)$ dan sisanya 32 mahasiswa (8\%) berpendapat bahwa tindakan mahasiswa ketika sulit mendapatkan buku referensi original adalah dengan meminjam pada orang lain/kakak tingkat yang memiliki buku asli. Dengan angka selisih persentase hanya terpaut $8 \%$ temuan ini menunjukan bahwa mahasiswa sudah terbiasa melakukan fotokopi buku apabila mereka tidak menemukan buku tersebut di perpustakaan.

\footnotetext{
${ }^{3}$ Asih dan Pratiwi, "Perilaku Prososial ditinjau dari Empati dan Kematangan Emosi," Jurnal Psikologi I, no 1. 2010: 38.
} 
Alfiah, Ismail, Darni: Budaya Mahasiswa dalam Menggunakan Pirated Books...

Kemudian dilihat dari kebiasaan (budaya) mahasiswa dalam mendapatkan buku referensi kuliah, sebagian besar mahasiswa sebanyak 354 mahasiswa $(88,5 \%)$ berpendapat kadang-kadang melakukan fotokopi buku kuliah. Namun jawaban pilihan kedua sebanyak 37 mahasiswa $(9,25 \%)$ untuk mendapatkan buku referensi kuliah dengan selalu melakukan fotokopi buku referensi kuliah. Artinya, dengan menfotokopi buku/membeli buku bajakan adalah solusi dalam mendapatkan buku referensi kuliah.

Selanjutnya, dilihat dari kebiasaan (budaya) mahasiswa dari niat mahasiswa melakukan fotokopi buku referensi kuliah, sebagian besar mahasiswa sebanyak 220 mahasiswa $(55 \%)$ berpendapat bahwa niat mahasiswa melakukan fotokopi buku referensi kuliah dari niat diri sendiri. Dari temuan tersebut hampir separuh mahasiswa melakukan fotokopi buku tanpa dipaksa. Artinya, tanpa ditunjuk mahasiswa sudah tahu bagaimana untuk mendapatkan buku tersebut.

Selanjutnya, dilihat dari kebiasaan (budaya) mahasiswa dari teknis mahasiswa melakukan fotokopi buku referensi kuliah dan tempat langganan dalam fotokopi buku bagi mahasiswa, sebagian besar mahasiswa sebanyak 337 mahasiswa $(84,25 \%)$ menunjukkan bahwa cara mahasiswa melakukan fotokopi buku referensi kuliah dengan dikoordinasi oleh kelas. Sedangkan dalam mencari tempat fotokopi tersebut sebagian besar mahasiswa sebanyak 187 mahasiswa (46,75\%) menunjukkan bahwa punya tempat langganan fotokopi buku sendiri. Dari temuan ini, terlihat sudah terbagun suatu sistem yang sistematis dalam melakukan fotokopi buku. Dengan kata lain, pola yang dilakukan mahasiswa tersebut merupakan suatu kebiasaaan. Menurut Sayid, kebiasaan adalah pengulangan sesuatu secara terus-menerus atau dalam sebagian besar waktu dengan cara yang sama dan tanpa hubungan akal, atau dia adalah sesuatu yang tertanam di dalam jiwa dari hal-hal yang berulang kali terjadi dan diterima tabiat. ${ }^{4}$

Kemudian dilihat kebiasaan (budaya) mahasiswa dari alasan mahasiswa melakukan fotokopi buku referensi kuliah dan yang memotivasi mahasiswa untuk melakukan fotokopi buku di mana sebagian besar mahasiswa sebanyak 297 mahasiswa $(74,25 \%)$ menunjukkan bahwa alasan mahasiswa melakukan fotokopi buku referensi kuliah karena sudah terbiasa dengan fotokopi buku untuk memiliki buku referensi kuliah. Sedangkan sebagian besar mahasiswa sebanyak 259 mahasiswa $(64,75 \%)$ mengatakan bahwa yang memotivasi untuk melakukan fotokopi buku adalah diri

${ }^{4}$ Muhammad Sayid, Kebiasaan... 
sendiri. Dari temuan ini, secara alami mahasiswa cenderung sudah terbiasa dengan namanya buku fotokopian. Walupun kualitasnya tidak sebagus buku aslinya namun tetap menjadi pilihan utama bagi mahasiswa.

\section{Kesimpulan}

1. Analisis faktor ekonomi mahasiswa menunjukan bahwa budaya mahasiswa dalam menggunakan buku bajakan (pirated books) bukan penyebabnya dari faktor ekonomi. Hal ini dibuktikan, sebagian besar mahasiswa sebanyak 193 mahasiswa $(48,25 \%)$ memiliki belanja bulanan Rp 1.000.000 - Rp 2.000.000 ada, sebanyak 309 mahasiswa (77,25\%) menggunakan sepeda motor menuju kampus, menggunakan smartphonelhandphone dengan harga Rp. 1.000 .000 - Rp. 2.0000.000. Walaupun sebagian besar mahasiswa sebanyak 176 mahasiswa (44\%) pekerjaan orang tua mahasiswa adalah petani, namun dengan kondisi ekonomi yang cukup baik atau digolongkan taraf menegah ke bawah.

2. Pemahaman mahasiswa tentang hak cipta menunjukan bahwa mahasiswa memahami dan mengerti tentang hak cipta. Hal ini dibuktikan dengan sebagian besar mahasiswa sebanyak 274 mahasiswa $(68,5 \%)$ berpendapat bahwa hak cipta adalah suatu hak agar ciptaannya tidak ditiru oleh orang lain, sebagian besar mahasiswa sebanyak 357 mahasiswa $(89,25 \%)$ berpendapat bahwa yang dianggap sebagai pencipta adalah seseorang yang melahirkan suatu ciptaan berdasar kreativitasnya yang dituangkan ke dalam bentuk yang khas, sebagian besar mahasiswa sebanyak 340 mahasiswa (85\%) berpendapat bahwa yang tidak dianggap sebagai pelanggaran hak cipta. Walaupun sebanyak 194 mahasiswa $(48,5 \%)$ melakukan fotokopi buku untuk kepentingan pendidikan tidak melanggar hak cipta karena untuk mempermudah menuntut ilmu pengetahuan. Sebenarnya fotokopi buku untuk kepentingan pendidikan tidak melanggar hak cipta untuk mempermudah menuntut ilmu pengetahuan pada dasarnya adalah sebuah tindakan pelanggaran hak cipta karena termasuk tindakan memperbanyak tanpa izin dan menyebarluaskannya.

3. Sikap mahasiswa akan buku fotokopi/bajakan biasa biasa saja atau sudah terbiasa dengan buku fotokopi/bajakan. Hal ini dibuktikan dari sebagian besar mahasiswa sebanyak 182 mahasiswa (45,5\%) memiliki jumlah buku fotokopi antara 4-6 buah 
Alfiah, Ismail, Darni: Budaya Mahasiswa dalam Menggunakan Pirated Books...

buku, perasaan mahasiswa melakukan fotokopi buku referensi kuliah menunjukkan bahwa sebagian besar mahasiswa yang melakukan fotokopi buku referensi kuliah merasa biasa-biasa saja sebanyak 281 mahasiswa $(70,25 \%)$.

4. Kebiasaan (budaya) mahasiswa dalam membeli buku rujukan kuliah di mana membeli buku referensi fotokopi/bajakan sudah merupakan kebiasaan mahasiswa. Hal ini di buktikan dengan ada 167 mahasiswa (41,75\%) ketika sulit mendapatkan buku referensi original adalah dengan memfotokopi buku tersebut, dalam mendapatkan buku referensi kuliah, di mana sebagian besar mahasiswa sebanyak 354 mahasiswa $(88,5 \%)$ berpendapat kadang-kadang melakukan fotokopi buku kuliah, sebagian besar mahasiswa sebanyak 220 mahasiswa (55\%) berpendapat bahwa niat mahasiswa melakukan fotokopi buku referensi kuliah dari niat diri sendiri, sebagian besar mahasiswa sebanyak 337 mahasiswa $(84,25 \%)$ bahwa cara mahasiswa melakukan fotokopi buku referensi kuliah dengan dikoordinasi oleh kelas, sebagian besar mahasiswa sebanyak 297 mahasiswa (74,25\%) menunjukkan bahwa alasan mahasiswa melakukan fotokopi buku referensi kuliah karena sudah terbiasa dengan fotokopi buku untuk memiliki buku referensi kuliah, sebagian besar mahasiswa sebanyak 259 mahasiswa (64,75\%) menunjukkan bahwa yang memotivasi untuk melakukan fotokopi buku adalah Diri sendiri, dan sebagian besar mahasiswa sebanyak 187 mahasiswa (46,75\%) menunjukkan bahwa punya tempat langganan fotokopian buku.

\section{E. Daftar Pustaka}

Asih \& Pratiwi. "Perilaku Prososial ditinjau dari Empati dan Kematangan Emosi." Jurnal Psikologi I, no 1. (2010): 38.

Fatwa MUI Nomor 1 tahun 2003 tentang Hak Cipta

Ginting, Elyta Ras. Hukum Hak Cipta Indonesia. Bandung: PT. Citra Aditya Bakti.

Hamzah, Andi. Hukum Pidana yang Berkaitan dengan Komputer. Jakarta: Sinar Grafika, 1996.

Hartono. Metodologi Penelitian. Pekanbaru: Zanafa Publishing, 2011.

Hidayat, Anas \& Phau, Ian. "Pembajakan Produk: Dilema Budaya antara Barat Dan Timur Kajian Literatur pada Sisi Permintaan.” JSB 8, no. 2 (2003)

https://artikata.com/arti-359975-kebiasaan.html, diakses pada tanggal 18 Maret 2017.

Laksono, Probo. Faktor-Faktor Yang Mempengaruhi Intensi Mahasiswa di Yogyakarta untuk Menggunakan Software Bajakan. Yogyakarta: PFEUGM, 2008. 
Makarim, Edmon. Pengantar Hukum Telematika. Jakarta: PT. Raja Grafindo, 2005.

Marpaung, Leden. Tindak Pidana Terhadap Hak Atas Kekayaan Intelektual. Jakarta: Sinar Grafika, 1995.

Pusat Bahasa Departemen Pendidikan Nasional. Kamus Besar Bahasa Indonesia. Edisi 3 - Cet. 2. Jakarta: Balai Pustaka, 2002.

Rahmah. "Pengaruh Sikap, Norma Subjektif, dan Perceived Behavioral Control Terhadap Intensi Membeli Buku Referensi Kuliah Ilegal pada Mahasiswa UIN Syarif Hidayatullah Jakarta.” Skripsi. Jakarta: UIN Syarif Hidayatullah, 2011.

Sayid, Muhammad. Kebiasaan Baik dan Buruk dalam Hidup Manusia. Gema Insani Press Jakarta, 2006.

Sumarmo, Joko. "Minimalisai Pelanggaran Pendidikan di Sekolah Melalui Efektifitas Kinerja Tim Kedisiplinan.” Jurnal SMPN Bobot Sari Purbalingga. (2008): 1-8.

Trimo, Soejono. Buku Panduan untuk Matakuliah Reference Work dan Bibliography dengan Sistem Modular. Jakrata: Bumi Aksara, 1997.

Undang-undang No. 19 tahun 2002 tentang Hak Cipta. 